\title{
URBAN AND RURAL REPRESENTATION AND STATE LEGISLATIVE APPORTIONMENT
}

\author{
John P. White, Arizona State University \\ AND \\ Norman G. Thomas, University of Michigan
}

\begin{abstract}
The complexion of societies and civilizations change, often with amazing rapidity. A nation once primarily rural in character becomes predominantly urban. Representative schemes once fair and equitable become archaic and dated. (Chief Justice Warren, in Reynolds v. Sims.)
\end{abstract}

HE SUPREME COURT'S full acceptance, in the Reynolds case, of the doctrine of "one man, one vote" will, if implemented, unquestionably result in major shifts in the balance of power in state legislatures. The precise nature of these shifts is as yet unclear, and depends in part on subsequent judicial construction of the court's somewhat cryptic comments regarding permissible deviations from the equal population standards in order to achieve the objective of "insuring some voice to political subdivisions, as political subdivisions." 1 The shifts would also be negated should legislation be enacted or a constitutional amendment be ratified which would remove the matter of legislative apportionment from the jurisdiction of the Supreme Court.

The immediate popular analysis of the decision, however, stressed a major political victory of urban majorities over entrenched rural minorities. Some of the remarks of the Chief Justice, including the words quoted above, indicate that the court shared this belief to some extent. ${ }^{2}$ In order to understand whether this is an accurate assessment of the probable effects of the decision, we must first be able to measure effectively the incidence of over-and-under-representation in any given state. The courts, including state and lower federal courts, have significantly lacked any precise measuring device which might have accomplished this purpose. In plunging boldly into the mathematical quagmire, the court placed major reliance on two measuring devices: the range in population size between largest and smallest districts, ${ }^{3}$ and the "majority to elect" (Dauer-Kelsey scale).$^{4}$ Neither of these devices

12 L. Ed.2nd 506.

${ }^{2}$ In a footnote following the quoted remarks, Warren qualifies them by saying: "Although legislative apportionment controversies are generally viewed as involving urban-rural conflicts, much evidence indicates presently it is the fast-growing suburban areas which are the most seriously underrepresented in many of our state legislatures. And, while currently the thrust of state legislative malapportionment results, in most States, in underrepresentation of urban and suburban areas, in earlier times cities were in fact overrepresented in a number of States. ..." Ibid., at 530, n. 42.

${ }^{3}$ Cf. National Municipal League, Compendium on Legislative Apportionment (2nd ed.; Washington, 1962), passim. The summary table (pp. iii-iv) in this publication gives two items of information for each state, in addition to the average size of districts: one is the DauerKelsey scale, and the other is the range of population size. Range has apparently been almost universally cited by plaintiffs in suits attacking apportionments. Most apportionment opinions have referred to the range existing in the litigated apportionment, but there is nothing approaching unanimity among judicial attitudes toward this measurement, though a majority of the opinions seem to regard it as one piece of evidence to be considered, and a few apparently regard a wide range as conclusive evidence of unconstitu- 
can, or was intended to, measure the representation of rural and urban populations as such. Of course, if district population size alone is to be considered, such measures may be adequate (leaving aside questions of statistical appropriateness), but they can tell us nothing about probable shifts of political power between urban and rural populations. Nor can they help us evaluate the decision of the court in terms of the "gravity of the evil" of rural overrepresentation, which quite obviously was at least one consideration in the minds of the majority justices.

The purpose of this article is to describe a technique for measuring the representation of the rural and urban populations as such in all of the ninety-nine state legislative bodies. The technique used is an application of the David-Eisenberg indices, ${ }^{5}$ which measure "the value of the right to vote" in each of the counties of the United States, and for both houses of bicameral bodies. David and Eisenberg divided the average population of all districts in the body under study by the population of each legislative district, and multiplied the result by 100 . Thus, if all districts were of

tionality. Dicta in Scholle v. Hare, 376 Mich. 176, 116 N.W.2d 350 Michigan Supreme Court (1962), is to the effect that "When a legislative apportionment provides districts having more than double the population of others, the constitutional range of discretion is violated." (Opinion of Kavanagh, J.) Similarly, in Moss v. Burkhart, 207 F. Supp. 885 (1962), Oklahoma, the court appended to its opinion the testimony of Dr. Joseph Pray, a political scientist, who stated: "... to the extent you have one to 26 , you have a diffusion of suffrage power which is as bad as if the vote was not counted because of fraud. ..." On the other hand, Judge O. Bowie Duckett, of the Circuit Court for Anne Arundel County, Maryland, in the case of Maryland Committee for Fair Representation v. Tawes, opinion reproduced by photo offset in Court Decisions on Legislative Apportionment (New York, National Municipal League, 1962), 3 volumes, rather pointedly rejected the argument that the Maryland range was much worse ( 33 to 1 ) than that found repugnant in Michigan (12 to 1). Judge Duckett included this plea in a discussion of "points of little merit." The Maryland Court of Appeals upheld Judge Duckett's decision, 182 A.2d 877 (1962). Other cases in which range has been utilized in one way or another include: Toombs v. Fortson, 205 F. Supp. 248 (1962), Georgia; Sanders v. Gray, 203 F. Supp. 158 (1962), Georgia; WMCA v. Simon, 202 F. Supp. 741 (1962), New York; Sims v. Frink, 208 F. Supp. 431, Alabama; Sobel v. Adams, 208 F. Supp. 316 (1962), Florida ; Wisconsin v. Zimmerman, 209 F. Supp. 183 (1962), Wisconsin; Caesar v. Williams, 371 P.2d 241 (1962), Idaho; Sweeney v. Notte, 183 A.2d 817 (1962) Vermont; Lisco v. McNichols, 208 F. Supp. 471 (1962), Colorado; and Stein v. General Assembly, 374 P.2d 77 (1962), Colorado.

Similar use was made of the range in the Reynolds case, and in the accompanying cases decided on the same day.

A good discussion of the problems connected with the use of the range may be found in W. Allen Wallis and Harry V. Roberts, Statistics: A New Approach (Glencoe: Free Press, 1956), pp. 245-47. Wallis and Roberts charge that the Kinsey report came to some of its more interesting findings as a result of misusing the range.

Some of the rough evaluation systems proposed and actually used by courts seem to involve a failure to appreciate that overrepresentation should always be judged by looking at the other side of the coin: the effect of the overrepresentation on those underrepresented. We feel that the range is of dubious value, both statistically and historically. Almost any elementary statistics textbook warns against the misuse of the range as a measure of dispersion.

"Manning J. Dauer and Robert G. Kelsey, "Unrepresentative States," National Municipal Review (December 1955), pp. 571-5,587, as corrected in National Municipal Review (April $1956)$, p. 198.

- Paul T. David and Ralph Eisenberg, Devaluation of the Urban and Suburban Vote (Charlottesville: Bureau of Public Administration, University of Virginia, Vol. 1, 1961; Vol. $11,1962)$. For a discussion of the David-Eisenberg indices, as well as a proposal for a statistically sophisticated method of evaluating state legislative apportionment (with district population equality as the basic sandard), see Glendon Schubert and Charles Press, "Measuring Malapportionment," American Political Science Review, 58 (June 1964), $302-27$. 
equal population, each district (and every county) would have an index number of 100. A district which has twice the average population would have an index of 50 , signifying that each vote in the district has a weight of only 50 per cent of the state average, while a district with only half the average population would have an index number of 200, indicating that the value of the vote in such a district is twice as great as the state average. Since all the counties in a given legislative district necessarily have the same index number, it was possible to assign indices to every county in the United States.

Our technique for measuring rural and urban representation involves the weighting of the rural population, as reported in the 1960 census, by the DavidEisenberg indices. For each county, we have multiplied the actual rural population by the David-Eisenberg index for that county. We have thus computed a weighted, rural population for each state, the weighting being supplied, in effect, by the apportionment system in use in the state in 1960. Dividing the weighted rural population, for each state legislative chamber, by the state's actual rural population gives us the index of rural representation in that body. We determined the urban index by subtracting the weighted rural population for each chamber from the actual total population, arriving at a weighted urban population, and then dividing by the actual urban population.

Ninety-seven of the ninety-nine state legislative bodies, as of 1960 , were so apportioned as to give an advantage to the rural population. The only two exceptions are found in Massachusetts, where both houses slightly overrepresent the urban population.

Although Anglo-Saxon tradition has it that the upper house should be representative of special interests, there are twenty-one lower houses in which the rural population is more heavily weighted than in the corresponding upper house. Since there is no consistent pattern as between upper and lower houses, we have tabulated the data into two categories: those houses, whether upper or lower, which more closely approach straight popular representation (Table I), and those houses which are less popular (Table II).

What is the value of the data presented in tables I and II? In attempting to evaluate a state apportionment system as to the extent of rural overrepresentation, ${ }^{6}$ one might conceivably set some upper limit on the degree to which the rural population can be favored. But overrepresentation of any group is presumably offensive from a constitutional point of view only if it has a serious adverse effect on the rights and interests of other individuals or groups. Of course, any overrepresentation, of whatever degree, necessarily involves underrepresentation. Someone must pay the piper. But any conceivable system of apportionment will grant some advantage to certain individuals or groups. The scholar or the judge who wishes to evaluate a given apportionment system must evaluate the adverse effect of any overrepresenta-

\footnotetext{
"We wish to emphasize that we are using the terms "overrepresentation" and underrepresentation" in a purely descriptive statistical sense. It is not our intention in this article either to support or oppose the doctrine that population should be the sole standard for evaluating apportionment systems. We assume only that almost all contending parties, in the current national controversy regarding apportionment, will agree that it is a factor of primary importance which must be taken into account in evaluating apportionment systems.
} 
TABLE I

Rank Order Listing by Indices of Urban Representation in More Popular House of State Legislatures

\begin{tabular}{|c|c|c|c|c|c|c|c|c|c|}
\hline & State & House & $\begin{array}{l}\text { Urban } \\
\text { Index }\end{array}$ & $\begin{array}{l}\text { Rural } \\
\text { Index }\end{array}$ & & State & House & $\begin{array}{l}\text { Urban } \\
\text { Index }\end{array}$ & $\begin{array}{l}\text { Rural } \\
\text { Index }\end{array}$ \\
\hline 1. & Mass. & (U) & 100.8 & 96.1 & 26. & Wyo. & (L) & 88.4 & 115.2 \\
\hline 2. & N.J. & (L) & 99.7 & 102.5 & 27. & Va. & (U) & 87.7 & 115.4 \\
\hline 3. & Ohio & (U) & 99.2 & 102.5 & 28. & N.C. & $\left(\mathrm{U}^{\prime}\right)$ & 85.3 & 109.6 \\
\hline 4. & Wash. & (L) & 98.7 & 102.7 & 29. & Colo. & (L) & 85.1 & 141.8 \\
\hline 5. & N.H. & (U) & 98.5 & 102.0 & 30. & N.M. & (L) & 85.0 & 128.9 \\
\hline 6. & R.I. & (L) & 98.5 & 109.6 & 31. & Tenn. & (U) & 84.9 & 116.5 \\
\hline 7. & Calif. & (L) & 98.2 & 111.4 & 32. & Miss. & (U) & 84.8 & 109.2 \\
\hline 8. & Ill. & $(\mathrm{L})$ & 97.7 & 109.8 & 33. & Ky. & (U) & 84.2 & 112.7 \\
\hline 9. & Wis. & (L) & 97.6 & 104.2 & 34. & Neb. & & 81.9 & 121.6 \\
\hline 10. & Ariz. & (L) & 97.6 & 106.9 & 35. & Utah & (L) & 80.9 & 157.0 \\
\hline 11. & Maine & (L) & 96.4 & 103.8 & 36. & Minn. & $(\mathrm{U})$ & 80.5 & 132.1 \\
\hline 12. & N.Y. & (U) & 96.1 & 122.9 & 37. & Iowa & (U) & 79.7 & 122.9 \\
\hline 13. & Mich. & (L) & 96.0 & 110.0 & 38. & Md. & (L) & 78.6 & 156.9 \\
\hline 14. & Ore. & $(\mathrm{L})$ & 95.9 & 106.7 & 39. & S.D. & (L) & 78.4 & 114.0 \\
\hline 15. & Conn. & (U) & 95.9 & 114.9 & 40. & Kan. & (U) & 78.2 & 134.2 \\
\hline 16. & S.C. & $(\bar{L})$ & 95.2 & 103.4 & 41. & Okla. & (U) & 73.8 & 144.5 \\
\hline 17. & Hawaii & $(\mathbf{L})$ & 94.8 & 116.9 & 42. & Del. & (L) & 73.3 & 150.9 \\
\hline 18. & Penna. & (L) & 94.7 & 113.3 & 43. & Ida. & (L) & 73.2 & 124.2 \\
\hline 19. & Mo. & $(\mathrm{U})$ & 93.3 & 113.2 & 44. & Ala. & $(\mathrm{U})$ & 72.8 & 133.1 \\
\hline 20. & W. Va. & (U) & 91.2 & 105.5 & 45. & Alas. & (L) & 72.8 & 116.6 \\
\hline 21. & Ark. & (U) & 90.4 & 107.2 & 46. & Mont. & (L) & 71.9 & 128.3 \\
\hline 22. & Ind. & $(\mathbf{L})$ & 90.0 & 116.6 & 47. & Nev. & (L) & 70.7 & 169.6 \\
\hline 23. & Vt. & (U) & 89.7 & 106.4 & 48. & $\mathrm{Ga}$. & (U) & 68.4 & 131.9 \\
\hline 24. & La. & (L) & 89.0 & 118.9 & 49. & N.D. & (L) & 67.8 & 117.5 \\
\hline 25. & Tex. & (U) & 88.9 & 133.4 & 50. & Fla. & (L) & 66.9 & 194.0 \\
\hline
\end{tabular}

TABLE II

Rank Order Listing by Indiges of Urban Representation in Less Popular Houses of State Legislatures

\begin{tabular}{|c|c|c|c|c|c|c|c|c|c|}
\hline & State & House & $\begin{array}{l}\text { Urban } \\
\text { Index }\end{array}$ & $\begin{array}{l}\text { Rural } \\
\text { Index }\end{array}$ & & State & House & $\begin{array}{l}\text { Urban } \\
\text { Index }\end{array}$ & $\begin{array}{l}\text { Rural } \\
\text { Index }\end{array}$ \\
\hline $\begin{array}{l}1 . \\
2 . \\
3 . \\
4 . \\
5 . \\
6 . \\
7 . \\
8 . \\
9 . \\
10 . \\
11 . \\
12 . \\
13 . \\
14 . \\
15 . \\
16 . \\
17 . \\
18 . \\
19 . \\
20 . \\
21 . \\
22 . \\
23 . \\
24 . \\
25 .\end{array}$ & $\begin{array}{l}\text { Mass. } \\
\text { N.H. } \\
\text { Wash. } \\
\text { Wis. } \\
\text { Ore. } \\
\text { Penna. } \\
\text { R.I. } \\
\text { N.Y. } \\
\text { Ind. } \\
\text { Ill. } \\
\text { Maine } \\
\text { Tex. } \\
\text { Va. } \\
\text { Conn. } \\
\text { Ohio } \\
\text { W. Va. } \\
\text { Mich. } \\
\text { La. } \\
\text { Colo. } \\
\text { Wyo. } \\
\text { Neb. } \\
\text { N.J. } \\
\text { Ark. } \\
\text { S.C. } \\
\text { Tenn. }\end{array}$ & $\begin{array}{l}(\mathrm{L}) \\
(\mathrm{L}) \\
(\mathrm{U}) \\
(\mathrm{U}) \\
(\mathrm{L}) \\
(\mathrm{U}) \\
(\mathrm{U}) \\
(\mathrm{L}) \\
(\mathrm{U}) \\
(\mathrm{U}) \\
(\mathrm{U}) \\
(\mathrm{L}) \\
(\mathbf{L}) \\
(\mathrm{L}) \\
(\mathrm{L}) \\
(\mathrm{L}) \\
(\mathrm{U}) \\
(\mathrm{L}) \\
(\mathrm{U}) \\
(\mathrm{U}) \\
(\mathrm{U}) \\
(\mathrm{L}) \\
(\mathrm{U}) \\
(\mathrm{L})\end{array}$ & $\begin{array}{r}101.0 \\
98.0 \\
98.0 \\
96.0 \\
93.9 \\
92.0 \\
91.7 \\
91.6 \\
89.8 \\
89.5 \\
89.4 \\
88.0 \\
85.8 \\
85.2 \\
84.2 \\
83.8 \\
83.3 \\
83.0 \\
82.9 \\
82.3 \\
81.9 \\
81.7 \\
79.4 \\
77.9 \\
77.9\end{array}$ & $\begin{array}{r}95.1 \\
102.8 \\
104.3 \\
107.0 \\
110.1 \\
120.2 \\
153.2 \\
149.4 \\
116.9 \\
143.9 \\
111.1 \\
135.9 \\
117.8 \\
153.3 \\
143.5 \\
110.0 \\
146.3 \\
129.2 \\
147.7 \\
123.3 \\
121.6 \\
240.8 \\
115.5 \\
115.5 \\
124.2\end{array}$ & $\begin{array}{l}26 . \\
27 . \\
28 . \\
29 . \\
30 . \\
31 . \\
32 . \\
33 . \\
34 . \\
35 . \\
36 . \\
37 . \\
38 . \\
39 . \\
40 . \\
41 . \\
42 . \\
43 . \\
44 . \\
45 . \\
46 . \\
47 . \\
48 . \\
49 . \\
50 .\end{array}$ & $\begin{array}{l}\text { Vt. } \\
\text { Minn. } \\
\text { Ky. } \\
\text { Hawaii } \\
\text { N.C. } \\
\text { Utah } \\
\text { Ala. } \\
\text { Del. } \\
\text { Calif. } \\
\text { Iowa } \\
\text { S.D. } \\
\text { Okla. } \\
\text { N.M. } \\
\text { N.D. } \\
\text { Kan. } \\
\text { Mo. } \\
\text { Ariz. } \\
\text { Fla. } \\
\text { Miss. } \\
\text { Alas. } \\
\text { Md. } \\
\text { Ga. } \\
\text { Ida. } \\
\text { Nev. } \\
\text { Mont. }\end{array}$ & $\begin{array}{l}(\mathrm{L}) \\
(\mathrm{L}) \\
(\mathrm{L}) \\
(\mathrm{U}) \\
(\mathrm{L}) \\
(\mathrm{U}) \\
(\mathrm{L}) \\
(\mathrm{U}) \\
(\mathrm{U}) \\
(\mathrm{L}) \\
(\mathrm{U}) \\
(\mathrm{L}) \\
(\mathrm{U}) \\
(\mathrm{U}) \\
(\mathrm{L}) \\
(\mathrm{L}) \\
(\mathrm{U}) \\
(\mathrm{U}) \\
(\mathrm{L}) \\
(\mathrm{U}) \\
(\mathrm{U}) \\
(\mathrm{L}) \\
(\mathrm{U}) \\
(\mathrm{L}) \\
(\mathrm{U})\end{array}$ & $\begin{array}{l}77.8 \\
77.7 \\
76.8 \\
75.7 \\
75.1 \\
75.0 \\
72.1 \\
71.4 \\
70.7 \\
70.7 \\
69.7 \\
69.0 \\
68.3 \\
67.1 \\
66.7 \\
65.7 \\
65.1 \\
65.0 \\
63.9 \\
63.0 \\
60.9 \\
60.2 \\
56.4 \\
38.6 \\
29.4\end{array}$ & $\begin{array}{l}113.9 \\
136.7 \\
118.6 \\
179.5 \\
116.3 \\
174.6 \\
107.0 \\
110.1 \\
285.8 \\
153.2 \\
119.6 \\
152.6 \\
161.2 \\
117.9 \\
152.1 \\
168.4 \\
202.2 \\
199.4 \\
121.8 \\
122.2 \\
204.0 \\
149.2 \\
139.5 \\
245.8 \\
171.0\end{array}$ \\
\hline
\end{tabular}


tion that may be identified. On the principle de minimus, we are not likely to worry if we find that some small group of individuals, such as fertilizer salesmen or circus ringmasters, is greatly overrepresented as a result of the fortuities of their places of residence and the peculiarities of the apportionment system.

What is needed, then, is a method of evaluating the effects of rural overrepresentation on urban dwellers. ${ }^{7}$ We have developed an application of the basic data presented in tables I and II which we believe will make this possible. The first step is to ascertain the effect of the apportionment system in a given state on the population balance between urban and rural in each state. To do this, we can weight the rural percentage of the population by the indices given in the two tables. If a given state has a population which is 50 per cent rural, and the rural population is weighted at 110 and 120 respectively in the two houses of the legislature, the weighted rural population percentages would be 55 and 60 , respectively. These weighted rural percentages are given in Table III. A comparison of Table III with the preceding two illustrates the danger of overreliance on any measure of the overrepresentation of a given group or area. The greatest overrepresentation of the rural population does not necessarily produce the greatest underrepresentation of urban dwellers. The larger the urban population, the more painlessly it may absorb rural overrepresentation. But when the shoe is on the other foot, and urban dwellers are in the minority or in a small majority, even apparently moderate overrepresentation of the rural population may dilute the urban vote quite seriously.

The statistics on weighted rural percentages of the population invite their classification into four categories directly related in the distribution of political power within a state:

\section{States in which an Existing Rural Majority $W$ as Strengthened}

There were eleven states in which there was a rural majority. In all of these, the 1960 rural majority was overrepresented in both houses of the legislature, usually in a serious fashion. This in itself is an interesting commentary on the widely believed notion that rural overrepresentation is largely a device to protect an embattled rural minority from the hordes of the great cities. But in Alaska, Arkansas, Idaho, Kentucky, Mississippi, North Carolina, North Dakota, South Carolina, South Dakota, Vermont, and West Virginia, an urban minority, far from getting special protection for its interests, found its limited political power further eroded by favoritism toward a more numerous rural population.

\section{States in which an Artificial Rural Majority Was Created in Both Houses of the Legislature}

There were thirteen states, over a fourth of the total, in which an urban majority was transmuted into a rural majority in both houses by the apportionment system. (This includes Nebraska's unicameral legislature.) In addition to Nebraska, the states in this category were Alabama, Delaware, Florida, Georgia, Iowa, Kansas, Maine, Montana, Nevada, Oklahoma, Tennessee, and Virginia. In most of these states, the transformation was startling in its thoroughness. A 30 per cent rural

\footnotetext{
${ }^{\top}$ David and Eisenberg, op. cit.
} 
TABLE III

Rural Percentages of State Population Weighted by Apportionment

\begin{tabular}{|c|c|c|c|c|}
\hline Actual & Actual Rural Percentage & $\begin{array}{c}\text { WEIGHTED RURA } \\
\text { More Popular } \\
\text { House }\end{array}$ & $\begin{array}{c}\text { LERCENTAGES } \\
\text { Less Popular } \\
\text { House }\end{array}$ & $\begin{array}{c}\text { Artificial } \\
\text { Majorities } \\
\text { Created }\end{array}$ \\
\hline (1) & 45.15 & $60.09(\mathrm{U})$ & $60.41 \quad(\mathrm{~L})$ & 2 \\
\hline Alas. & 62.07 & $72.37 \quad(\mathrm{~L})$ & $75.85(\mathrm{U})$ & - \\
\hline Ariz. & 25.46 & $27.22 \quad(\mathrm{~L})$ & $51.48(\mathrm{U})$ & 1 \\
\hline Ark. & 57.13 & $61.24(\mathrm{U})$ & 66.61 (L) & - \\
\hline 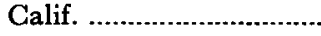 & 13.64 & $15.19(\mathrm{~L})$ & 38.98 (U) & 0 \\
\hline Colo. & 26.29 & 37.28 (L) & $38.83(\mathrm{U})$ & 0 \\
\hline Conn. & 21.68 & $24.91(\mathrm{U})$ & $33.24(\mathrm{~L})$ & $\mathbf{0}$ \\
\hline Del. & 34.39 & $51.89(\mathrm{~L})$ & $53.10(\mathrm{U})$ & 2 \\
\hline 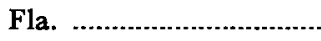 & 26.05 & $50.54(\mathbf{U})$ & $51.94(\mathrm{~L})$ & 2 \\
\hline Ga. & 44.70 & $62.18(\mathrm{U})$ & 66.69 (L) & 2 \\
\hline Hawaii & 23.51 & 27.55 (L) & $42.20(\mathrm{U})$ & 0 \\
\hline Ida. & 52.47 & 65.17 (L) & $73.20(\mathrm{U})$ & - \\
\hline Ill. & 19.26 & 21.15 (L) & $27.72(\mathrm{U})$ & 0 \\
\hline Ind. & 37.58 & 43.82 (L) & 43.93 (U) & 0 \\
\hline Iowa & 46.96 & $57.71(\mathrm{U})$ & $62.50 \quad(\mathrm{~L})$ & 2 \\
\hline Kan. & 39.00 & $52.34(\mathrm{U})$ & 59.32 (L) & 2 \\
\hline Ky. & 55.45 & $62.49(\mathrm{U})$ & 65.76 (L) & - \\
\hline La. & 36.73 & $43.67(\mathrm{U})$ & 44.77 (L) & 0 \\
\hline Me. & 48.71 & $50.56(\mathrm{~L})$ & 54.12 (U) & 2 \\
\hline 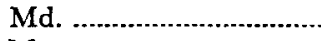 & 27.31 & 42.85 (L) & $55.71(\mathrm{U})$ & 1 \\
\hline 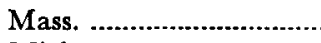 & 16.43 & $15.79(\mathrm{U})$ & $15.62(\mathrm{~L})$ & $\mathbf{0}$ \\
\hline Mich. & 26.63 & $29.56(\mathrm{~L})$ & $38.96(\mathrm{U})$ & 0 \\
\hline Minn. & 37.82 & 49.96 (U) & $51.70 \quad(\mathrm{~L})$ & 1 \\
\hline 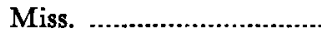 & 62.31 & 68.04 (L) & 75.89 (U) & - \\
\hline Mo. & 33.41 & 37.85 (U) & $56.26(\mathrm{~L})$ & 1 \\
\hline Mont. & 49.84 & 63.94 (L) & $85.23(\mathrm{U})$ & 2 \\
\hline Neb. & 45.72 & 55.60 (Unice & meral) & 1 \\
\hline Nev. & 29.64 & 50.27 (L) & $72.86(\mathrm{U})$ & 2 \\
\hline N.H. & 41.71 & $42.54(\mathrm{U})$ & 42.88 (L) & 0 \\
\hline N.J. & 11.41 & $11.70(\mathrm{~L})$ & $27.48(\mathrm{U})$ & 0 \\
\hline 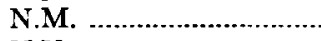 & 34.12 & 43.98 (L) & $55.00(\mathrm{U})$ & 1 \\
\hline N.Y. & 14.60 & $17.94(\mathrm{U})$ & $21.81 \quad(\mathrm{~L})$ & 0 \\
\hline N.C. & 60.55 & $66.25(\mathrm{U})$ & $70.30 \quad(\mathrm{~L})$ & - \\
\hline N.D. & 64.78 & 76.12 (L) & $76.39(\mathrm{U})$ & - \\
\hline Ohio & 26.61 & $27.22(\mathrm{U})$ & $38.19(\mathrm{~L})$ & $\mathbf{0}$ \\
\hline Okla. ....................... & 37.08 & $53.58(\mathrm{U})$ & $56.58(\mathrm{~L})$ & 2 \\
\hline Ore. & 37.80 & $40.33(\mathrm{~L})$ & $41.62(\mathrm{U})$ & 0 \\
\hline Pa. .................. & 28.42 & 32.20 (L) & $34.16(\mathrm{U})$ & 0 \\
\hline R.I. & 13.56 & $14.86(\mathrm{~L})$ & $20.77(\mathrm{U})$ & $\mathbf{0}$ \\
\hline S.C. & 58.81 & 60.81 (L) & $67.93(\mathrm{U})$ & - \\
\hline S.D. & 60.73 & $69.23(\mathrm{~L})$ & $72.63(\mathrm{U})$ & - \\
\hline Tenn. & 47.72 & $55.59(\mathrm{U})$ & 59.27 (L) & 2 \\
\hline Tex. & 24.97 & $33.30(\mathrm{U})$ & $33.93(\mathrm{~L})$ & 0 \\
\hline Utah & 25.09 & $39.39(\mathrm{~L})$ & 43.81 (U) & 0 \\
\hline Vt. & 61.54 & $65.48(\mathrm{U})$ & 70.09 (L) & - \\
\hline Va. & 44.41 & $51.24(\mathrm{U})$ & 52.31 (L) & 2 \\
\hline Wash. & 31.89 & 32.75 (L) & $33.26(\mathrm{U})$ & 0 \\
\hline W. Va. & 61.77 & $65.17(\mathrm{U})$ & $67.95(\mathrm{~L})$ & 一 \\
\hline Wis. & 36.77 & $37.70(\mathrm{~L})$ & 38.70 (U) & 0 \\
\hline Wyo. & 43.17 & 49.73 (L) & $53.23(\mathrm{U})$ & 1 \\
\hline
\end{tabular}


minority in Nevada became 50 per cent in one house and 73 per cent in the other, and a strong rural minority in Virginia (44 per cent) became an overwhelming majority in both houses (65 and 70 per cent, respectively). Maine is an exception to this, however. There a very small urban majority was pushed over the line into minority status in both houses, but the change was only from an actual 49 per cent to 52 and 54 per cent, respectively.

\section{States in which an Artificial Rural Majority was Created in One House Only}

There were six states in this group: Arizona, Maryland, Minnesota, Missouri, New Mexico, and Wyoming. In all except Arizona, the rural minority was substantially overrepresented in both houses, but there was still a weighted urban majority in one house. The relative smallness of the group is evidence that most apportionment systems do not have as widely divergent effects on rural population in the two houses of bicameral system as is often supposed. In fact, there were only four states in the Union (Montana, Nevada, New Mexico, and Ohio) in which the weighted rural population in one house was as much as 10 percentage points greater than in the other.

\section{States in which an Urban Majority Was Retained in Both Houses}

Of the thirty-nine urban states, twenty retain an urban majority in both houses. This group includes all states not classified in Groups 1-3. In all of these states except Massachusetts, the urban majority was attenuated by the apportionment system. It is significant, however, that all of the largest states are in this group. The most populous states tend to be the most urbanized, and as noted earlier, are more able to absorb rural overrepresentation without disastrous dilution of the urban majority. California is the best example. In the California Senate, the rural population enjoys the greatest overrepresentation in the United States, with an index of 286 . Yet because California is less than 14 per cent rural, the weighted rural population for the California Senate is only 39 per cent of the total. A similar situation exists in New Jersey, with its constitutional requirement of one senator per county, resulting in a rural index of 241. New Jersey is the most heavily urban state in the nation, and the weighted rural population for the Senate is only 27 per cent.

Of the eight states which are at least 75 per cent urban, all fall into Group 4, still further evidence that the most severe apportionment discriminations are not against the big urban majorities, but against urban minorities and small majorities.

\section{A Two-Drmensional Scheme for Evaluating Urban Representation}

While the above classification is, we believe, useful for illustrating shifts in the distribution of urban and rural political power as a result of apportionment provisions and action or inaction, and is therefore pertinent evidence to be considered in evaluating a state apportionment, it is perhaps necessary to apply some other standard than that of the shifting majority. As noted above, there are instances e.g., Maine - where a transformation in majorities has taken place despite relatively moderate rural overrepresentation, and other states where no such shift has occurred despite very large differences between real and weighted rural percentages. 
Devising a measurable single standard for evaluating apportionments is most difficult. A major problem in the creation of such a standard is inherent in the bicameral system. How is it possible to summarize, say in a single index number, the effect of two different apportionment systems applying to the two houses of a given legislature? Some use has been made of the technique of averaging index numbers for the two houses. David and Eisenberg have computed such an average for all counties and districts. ${ }^{8}$ Alan L. Clem has utilized a bicameral average in evaluating the apportionment of five mid-western states. ${ }^{9}$ We have preferred to avoid the utilization of averages. The average will operate to conceal significant differences between the two houses, and will make quite dissimilar apportionments appear to be identical in their effect. Thus, if we have one legislature in which the rural population has a weight of 75 in one house and 125 in another, the average would be 100 .

In evaluating the constitutionality or the political wisdom of a given overrepresentation of rural population, we would suggest, on the basis of our previous analysis, that major emphasis must be placed on the measurement of the effect on the urban population rather than on the isolated calculation of a ratio of overrepresentation of the rural population alone. We would further suggest that the evaluation must comprehend the entire apportionment, rather than isolated extreme cases.

If we are to understand the degree of urban underrepresentation in the fortynine bicameral systems on the eve of the Baker and Reynolds decisions, it is necessary somehow to retain in a single measure the integrity of the individual measurements of both houses of each bicameral legislature. Following Baker and before Reynolds, there seemed to be ample grounds for the prediction made by Solicitor General Archibald Cox in his widely quoted address to the Tennessee Bar Association in June 1962:

I do not mean to suggest how the question should be decided, but it would not surprise me greatly if the court were to hold that if seats in one branch of the legislature are apportioned in direct ratio to population, the allocation of seats in the upper branch may recognize historical, political and geographic subdivisions provided that the departure from equal representation in proportion to the population is not too extreme. But surely a very strong argument can also be made that there must be representation proportionate to the population in at least one branch of the legislature. ${ }^{10}$

The court's sweeping rejection of the federal analogy, and indeed of every standard save equal populations in both houses of every legislature, made it unnecessary for the courts to develop any ground rules for the application of the Cox formula. Had it been adopted by the court, subsequent litigation might have revealed the extent to which state apportionment systems represented population strictly in one house, while producing moderate but substantial deviations from the population standard in the other house. Despite, or perhaps because of, the court's adop-

\footnotetext{
${ }^{8}$ Ibid.

${ }^{9}$ Alan L. Clem, "Legislative Malapportionment and the Mathematical Quagmire," paper read at annual meeting of Midwest Conference of Political Scientists, April 27, 1962 (mimeographed).

${ }^{10}$ Quoted, with emphasis indicated, in Maryland Committee for Fair Representation v. Tawes (Supplemental Opinion), loc. cit. Subsequently, in his amicus brief in the Reynolds case, the Solicitor General argued for the standard set forth in his earlier speech. See Justice Stewart's dissent in WMCA v. Lomenzo. 12 L. Ed.2d 568, n. 16 at 591.
} 
tion of a single standard for both houses, it remains important to make such an inquiry, both from the point of view of evaluating the action of the court, and in order to assess the probability of urban-rural shifts in political power which may arise as a result of the Reynolds decision.

If we define a "population" house as one in which the urban population has not less than 90 per cent of its full population entitlement, and if we further assume that the moderate but substantial deviation suggested by Cox for the other house would produce an urban representation of not less than 75 per cent, we can then evaluate the apportionment system of each state as it existed prior to the Baker and Reynolds decisions. To be sure, the 90-75 standard is arbitrary, and can be no more than a rule of thumb. In any event, the determination of specific allowable percentages is not crucial to our technique of measurement. Utilizing the data presented below, the reader may apply whatever standards seem appropriate to him.

In presenting our data, we have found it helpful to utilize a graphic presentation of the pertinent data (See Figure 1). Since it is necessary to combine two measures into one, we have plotted on the vertical axis the index of urban representation in the more popular house, i.e., in the house with the lesser overrepresentation of rural population, disregarding whether this happens to be the upper or lower house. On the horizontal axis we have plotted the index of urban representation in the less popular house. We are thus able to plot each state at a single point on the graph. We

FIGURE 1

Two Dimensional Classification of Urban Representation in State Legislatures

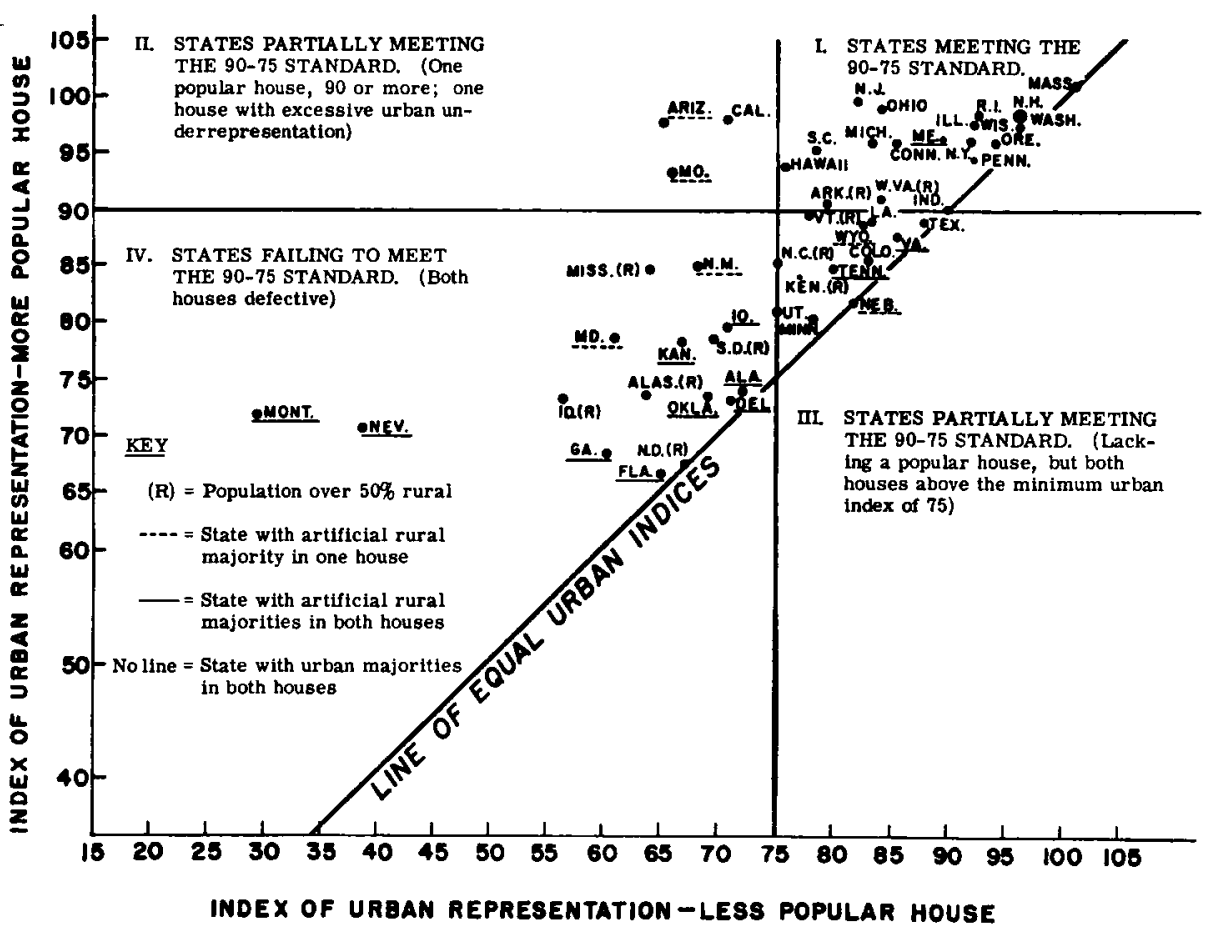


can also indicate our chosen limits of deviation by drawing a line across the graph at the index of 90 for the more popular house (which is plotted on the vertical axis), and another line from the top to the bottom of the graph at the index of 75 for the less popular house (plotted on the horizontal axis). We thus divide our graph into four rather unequal quadrants. In the process, we also group the states into four categories, based on their respective positions on the graph.

In the upper right-hand quadrant, we find twenty states which meet the 90-75 standard. That is, in all of these states, the urban population is weighted at not less than 90 per cent of actual in one house, and at not less than 75 per cent of actual in the other.

In the upper left-hand quadrant there are only three states: Arizona, California, and Missouri. These are the states which have one house which meets the standard of strict popular representation, but in which the other house exceeds the allowable dilution of the urban vote. It should be noted that California misses the acceptable category only slightly.

In the lower right-hand quadrant, we have a group of eleven states, in which neither house meets the standard of 90 per cent, but in which the less popular house is within the 75 per cent limit. ${ }^{11}$ In these states, the remedy needed would be to reapportion one house along strict population lines.

Finally, in the lower left-hand quadrant, we come to the rejects: the sixteen states in which both houses fail to meet our standards. Most of them are not even close to compliance in either house.

In addition to the graphic presentation, we have tabulated these four groups in Table IV, together with supplementary information about each state.

An analysis of the graphical presentation in Figure 1, and the accompanying information in Table IV, reveals some significant facts. Sixteen of the twenty states in Group 1, the acceptable category according to the 90-75 standard, have urban majorities. In only one state, Maine, is a rural minority converted to a legislative majority through the apportionment system. The Maine case can largely be discounted because of the thin margin of the actual urban majority ( 51.29 per cent urban), and the moderate degree of rural overrepresentation (103.8 per cent in the more popular house and 111.1 per cent in the less popular house). Also, Group 1 includes all of the large industrial states which are usually considered "pivotal" in a presidential election, with the exceptions of California and Texas which are not far away from the group. ${ }^{12}$

At the other extreme, Group 4 is composed of five rural states, nine urban states in which the apportionment system creates an artificial rural majority in both houses of the legislature, and two urban states in which an artificial rural majority is formed in one legislative house. In only three of those urban states, Florida, Maryland, and

\footnotetext{
${ }^{11}$ Nebraska's unicameral system is included in this group.

12 The "pivotal" states include, Illinois, Massachusetts, Michigan, New Jersey, New York, Ohio, Pennsylvania, Texas, and California. In California, the less popular house falls only 4.3 points short of meeting the standard of 75 per cent representation for the urban population. The more popular house is well over the 90 per cent minimum. In Texas, the less popular house is well over 75 in its urban index while the more popular falls 1.1 points short of the required 90 .
} 
Nevada, does the urban population exceed 70 per cent of the total. In each of those heavily urban states, the apportionment systems massively overrepresent the rural populace in order to produce the rural majorities in the legislatures involved. ${ }^{13}$ In the other states, the degree of rural overrepresentation is considerably less.

This analysis clearly illustrates the point suggested earlier: that the overrepresentation of the rural population is a far more serious problem in those states having a small urban majority or an urban minority. In such instances, even a moderate amount of rural overrepresentation can have serious effect on the representation of the urban population. Conversely, a state having a large urban population can tolerate a substantial degree of rural overrepresentation without serious consequences.

\section{TABLE IV}

Clas sification of States Based Upon 90-75 Rule of Urban Representation

\begin{tabular}{|c|c|c|c|}
\hline \multicolumn{3}{|c|}{$\begin{array}{l}\text { Group 1. } \\
\text { (Not less than } 90 \text { in one house, } 75 \text { in the other) }\end{array}$} & \multirow{2}{*}{$\begin{array}{l}\text { Irtificial Rural Majorities } \\
\text { reated by Apportionment }\end{array}$} \\
\hline $\begin{array}{r}U r b a n \\
M\end{array}$ & $\begin{array}{l}\text { or Rural } \\
\text { ajority }\end{array}$ & $\stackrel{\text { Art }}{\text { Cre }}$ & \\
\hline 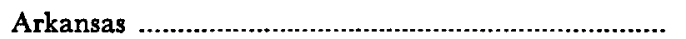 & $\mathbf{R}$ & & - \\
\hline Connecticut & $\mathbf{U}$ & $\because$ & 0 \\
\hline Hawaii & $\mathrm{U}$ & $\therefore:$ & 0 \\
\hline Illinois & $\mathbf{U}$ & & 0 \\
\hline Indiana & $\mathbf{U}$ & & $\mathbf{0}$ \\
\hline Maine & $\mathrm{U}$ & & 2 \\
\hline 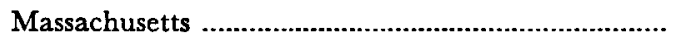 & $\mathrm{U}$ & & 0 \\
\hline Michigan & $\mathrm{U}$ & & 0 \\
\hline 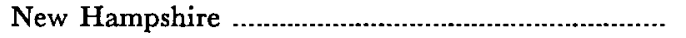 & $\mathbf{U}$ & .. & $\mathbf{0}$ \\
\hline 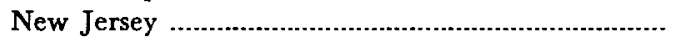 & $\mathbf{U}$ & & 0 \\
\hline 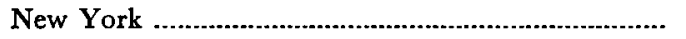 & $\mathbf{U}$ & & 0 \\
\hline Ohio & $\mathbf{U}$ & & 0 \\
\hline Oregon & $\mathbf{U}$ & & $\mathbf{0}$ \\
\hline 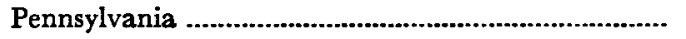 & $\mathbf{U}$ & & 0 \\
\hline Rhode Island & $\mathbf{U}$ & & $\mathbf{0}$ \\
\hline 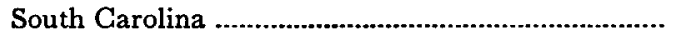 & $\mathbf{R}$ & & - \\
\hline 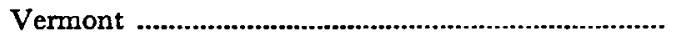 & $\mathbf{R}$ & & - \\
\hline Washington & $\mathrm{U}$ & & 0 \\
\hline 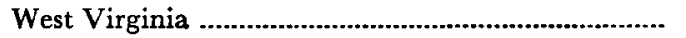 & $\mathbf{R}$ & & - \\
\hline Wisconsin & $\mathbf{U}$ & & 0 \\
\hline
\end{tabular}

Group 2.

(One popular house, 90 or more; one house with excessive rural overrepresentation, i.e., 75 or less)

\begin{tabular}{|c|c|c|}
\hline State & $\begin{array}{l}\text { Urban or Rural } \\
\text { Majority }\end{array}$ & $\begin{array}{l}\text { Artificial Rural Majorities } \\
\text { Created by Apportionment }\end{array}$ \\
\hline Arizona & ............. & 1 \\
\hline Californi & .......... & 0 \\
\hline Missouri & $\mathbf{U}$ & 1 \\
\hline
\end{tabular}

${ }^{18}$ The indices of rural representation are 194.0 and 199.4 in Florida, 156.9 and 204.0 in Maryland, and 169.6 and 245.8 in Nevada. 
TABLE IV (CONTINUED)

Classification of States Based Upon 90-75 Rule of Urban Representation

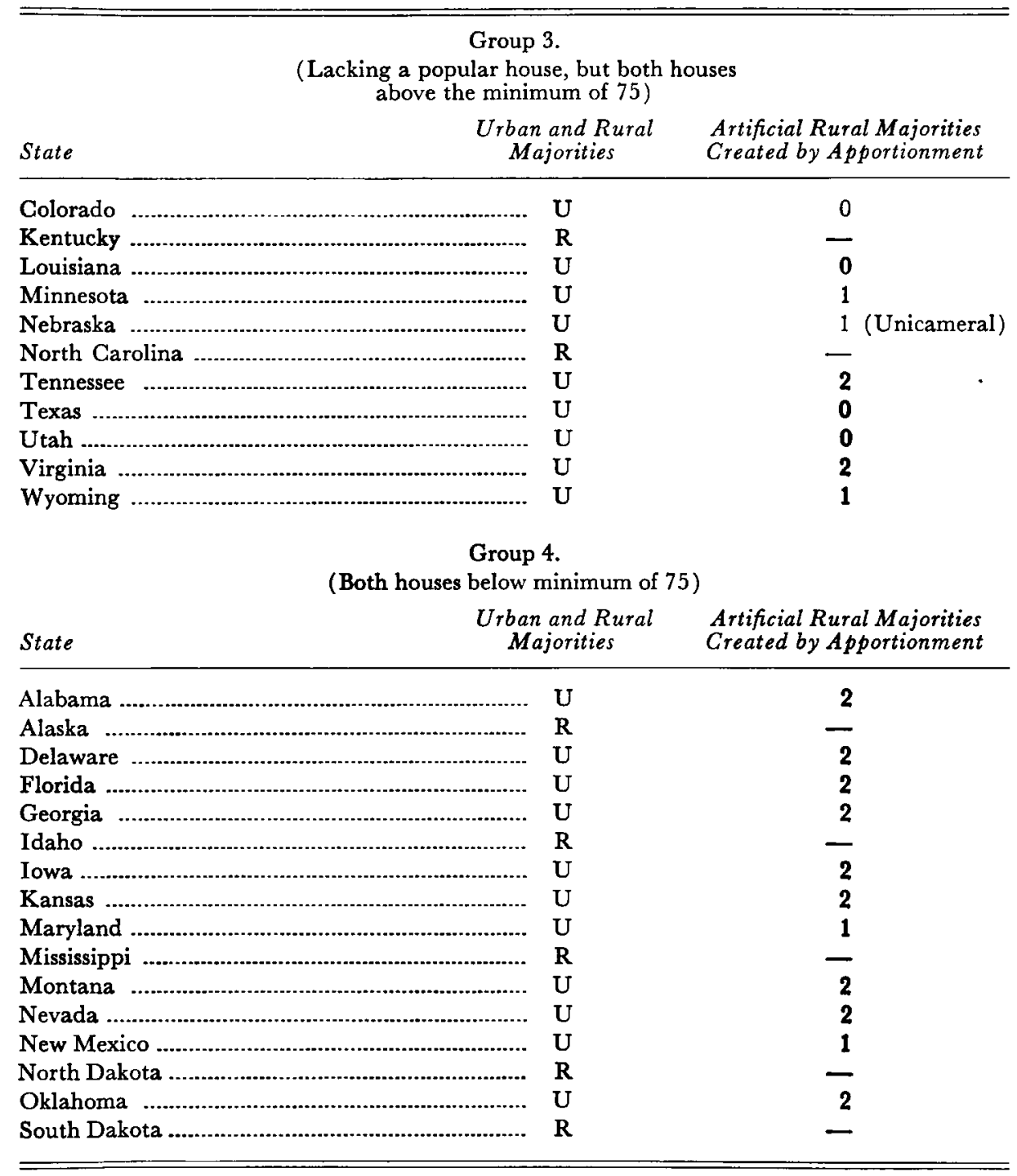

The point is further strengthened by the graphical representation of the 90-75 standard in Figure 2. The urban percentage of the population of a state is plotted on the vertical axis. The index of rural representation which can be permitted in a legislative body given a certain index of urban representation is plotted on the horizontal axis. The two curves represent the standard of an urban index of 90 in the more popular house and 75 in the less popular house. ${ }^{14}$ Thus a state with an urban

14 The two curves are derived from the mathematical relationship which exists between the urban and rural population of a state and from the indices of rural and urban representa- 
percentage of, say, 75, such as Texas or Utah, could permit a rural index of 130 in the more popular house and 180 in the less popular. On the other hand, a state which is 50 per cent urban, such as Montana, can permit rural indices of only 110 and 125 in its more and less popular houses if it is to comply with the 90-75 standard.

FIGURE 2

Permissible Degree of Rural Over-Representation Under A 90-75 Standard OF URBan REPRESENTATION

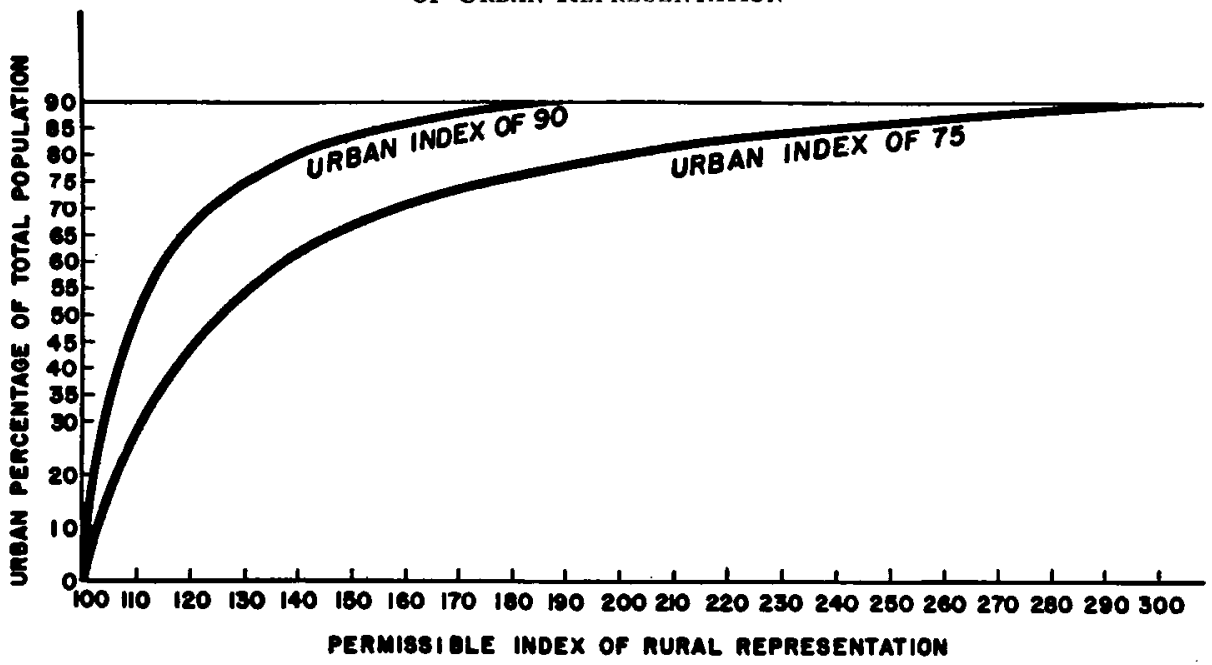

The 90 and 75 curves slope sharply upward as the urban percentage rises to a critical point (somewhere between 65 and 75 per cent urban) where relatively heavy rural overrepresentation can be tolerated. But below this point, ostensibly mild rural overrepresentation has an unacceptable effect on the representation of the urban population. ${ }^{15}$

tion in a state legislative body. This relationship is equal to the urban percentage of the population divided by the rural percentage. The same relationship exists between the degree of rural overrepresentation and urban underrepresentation. Thus:

$$
\mathbf{R}=\frac{\text { urban percentage }}{\text { rural percentage }} \text { and } \mathbf{R}=\frac{\text { Rural Index }-100}{100-\text { Urban Index }}
$$

The rural indices permissible with an urban index of 90 (the standard for the more popular house) are obtained from the formula:

$$
\text { Rural Index }=10 \times \frac{\text { urban \% }}{\text { rural \% }}+100
$$

Similarly, with an urban index of 75 (the standard for the less popular house);

$$
\text { Rural Index }=25 \times \frac{\text { urban \% }}{\text { rural \% }}+100
$$

${ }^{15}$ An infinite number of such curves can be drawn, depending upon the standards selected. It is possible to plot curves for an 85-70, a 90-60, or any other given standard.

In similar fashion, it is possible to evaluate the effects of an apportionment system upon any element of a state's population which can be identified and counted. The group may be geographic, occupational, racial, religious, political, or of any other identifiable characteristic. The indices of the group's representation in the state legislature can be calculated by applying the David-Eisenberg indices to the group membership in each county, a weighted vote for the group in each house of the legislature determined, and compared with the group's actual membership. The analysis can then be continued along lines we have followed here. It would thus be possible to determine, for example, the 
Referring to Figure 1, we note that there are sixteen states, excluding Nebraska, which have approximately the same degree of urban representation in both houses of their legislatures. ${ }^{16}$ The fact that these states are so widely dispersed on the graph indicates that there is no significant relationship between similar indices of representation of the urban population in the two legislative bodies and the acceptability of the apportionment system in terms of the 90-75 standard. It also indicates that, within the context of rural versus urban representation, the supposedly traditional practice of having one popular house and one house in which representation is based upon other factors is often ignored with varying effects upon the urban population.

Much of the current apportionment controversy focuses upon the type of system used. Although it is difficult to classify apportionment systems precisely because of the many variations in use, the six basic categories noted by Malcolm E. Jewell seem reasonable and comprehensive. ${ }^{17}$ Table $\mathrm{V}$ shows the number of houses apportioned under each system and the range of urban indices in each category. These data substantiate the normal expectation that while apportionment systems nominally based upon population achieve their presumed goals most imperfectly and unevenly, they do approach straight popular representation more closely than those systems which combine population and area. The combination systems, however, have generally less serious effects upon the urban populace than systems which provide equal apportionment for each unit or in which apportionment is fixed in the state constitution. The taxation system is not widely enough used to permit any evaluation.

As a check of the validity of our ranking of the states according to the representation of the urban population, we considered the possibility that our utilization

TABLE V

Apportionment Systems and Urban Representation

\begin{tabular}{|c|c|c|c|c|}
\hline \multirow[b]{2}{*}{ Types of Apportionment System } & \multirow{2}{*}{$\begin{array}{c}\text { Number of } \\
\text { Houses }\end{array}$} & \multicolumn{2}{|c|}{ RANGE OF URBAN } & \multirow{2}{*}{$\frac{\text { INDIGES }}{90-U p}$} \\
\hline & & Below 75 & $75-89$ & \\
\hline Straight Population . & 37 & 7 & 16 & 14 \\
\hline 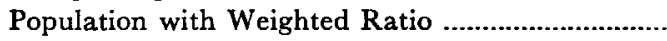 & 6 & 1 & 1 & 4 \\
\hline 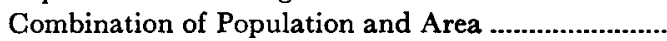 & 42 & 16 & 14 & 12 \\
\hline 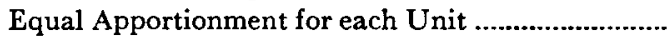 & $\ldots$ & 5 & 3 & 0 \\
\hline Fixed Constitutional Apportionment ....................... & $\ldots$ & 2 & 3 & $\mathbf{0}$ \\
\hline Taxation & 1 & 0 & 0 & 1 \\
\hline Total .......... & 99 & 31 & 37 & 31 \\
\hline
\end{tabular}

extent to which the white citizens of a state could afford to overrepresent a negro minority or the extent to which the citizens of Michigan's lower peninsula could afford to overrepresent the small $(3.9 \%)$ but significant geographic minority in its upper peninsula.

${ }^{16}$ These include Massachusetts, New Hampshire, Washington, Oregon, New York, and Pennsylvania in Group 1; Texas, Virginia, Colorado, and Minnesota in Group 2; and, Alabama, Delaware, Oklahoma, North Dakota, and Florida in Group 4.

${ }^{17}$ See "Constitutional Provisions for State Legislative Apportionment," Western Political Quarterly, 8 (June 1955), 271-79. Jewell's classifications include: Straight Population; Population with Weighted Ratio; Combination of Population and Area; Equal Apportionment for Each Unit; Fixed Constitutional Apportionment; and Taxation. 
of the urban-rural census categories might conceal variations in the representation of the most populous cities and counties. It might be objected that the urban census category includes inhabitants of very small towns as well as residents of metropolitan central cities. Apportionment controversies tend to involve alleged underrepresentation of relatively small areas of a given state, in which a large proportion of the state's population resides.

Since we wished to measure the representation of the classic opponents in the reapportionment struggle, the urban and the rural populations, we have accepted the census definition of those categories. We find, however, that our rankings would differ but little if we measured instead the representation of the population of the "majority counties" in each state (i.e., the smallest number of counties including a majority of the state's population). A rank ordering of the states on this basis is presented in tables VI and VII. It will be noted that the coefficient of rank-correlation between tables I and VI is .909, while that between tables II and VII is .819. This high correlation is not surprising in view of the concentration of urban population in the majority counties.

\section{Conclusions}

Our analysis suggests that while there is a genuine problem of urban underrepresentation, it is on the whole least severe in those highly urbanized states where the reapportionment battle has been the most bitter, and where the traditional rhetoric of urban-rural conflict has been most earnestly invoked, in and out of courtrooms. Many of the most important sources of political conflict in state government are not directly related to the urban-rural apportionment controversy. We feel that our findings tend to support the conclusions of other scholars. ${ }^{18}$ The intensity of the struggle over apportionment in states in the acceptable (Group 1) category of our analysis, e.g., Michigan, New York, and Wisconsin, strongly indicates that there are other significant factors beyond the scope of urban-rural conflict.

This does not mean that there is no serious problem in the representation of urban populations and interests. The present controversy demands a complete evaluation of the representative systems of our state governments. In many of our highly urbanized states, urban-based majorities have found it impossible to redirect public policy because they have been unable to win control of either or both houses of the

\footnotetext{
${ }^{18}$ See Robert S. Friedman, "Reapportionment Myth," National Civic Review, April 1960, pp. 184-88; and "The Urban-Rural Conflict Revisited," Western Political Quarterly, 14 (June 1961), 481-95; David R. Derge, "Metropolitan and Outstate Alignments in Illinois and Missouri Legislative Delegations," American Political Science Review, 52 (December 1958), 1051-65; and Robert H. Salisbury, "Missouri Politics and State Political Systems," Missouri Political Science Associations Research Papers 1958 (Columbia: Bureau of Governmental Research, University of Missouri, 1959), No. 2, p. 16.

For a somewhat contrary view, see Gordon E. Baker, Rural Versus Urban Political Power (Garden City: Doubleday, 1955). Our findings do not coincide with Baker's. He classified the states into five categories ( $p p .16-17$ ), on the basis of the representation of principal urban areas. The basis for the selection of these principal urban areas is not explicit, but apparently they were selected as examples of severe urban underrepresentation. While such a classification is useful for illustrating extreme degrees of underrepresentation, the method "cannot divulge a complete picture in any state" (p. 15), as Professor Baker notes. Our measurement has a different objective : to consider both overand underrepresentation of the total rural and urban population in each state.
} 
TABLE VI

Rank Order of Indices of Representation in House More Favorable to Counties Having Majority of State Population, 1960 Census*

\begin{tabular}{|c|c|c|c|c|c|c|}
\hline Rank & State & NUMBER & $\begin{array}{c}\frac{\text { F COUNTIES }}{\text { Including }} \\
\text { Majority of } \\
\text { Population }\end{array}$ & $\begin{array}{c}\text { Percentage } \\
\text { of State } \\
\text { Population }\end{array}$ & $\begin{array}{l}\text { Repres. } \\
\text { Index }\end{array}$ & $\begin{array}{c}\text { Upper or } \\
\text { Lower } \\
\text { House }\end{array}$ \\
\hline $\begin{array}{l}1 \\
2 \\
3 \\
4 \\
5 \\
6 \\
7 \\
8 \\
9 \\
10 \\
11 \\
12 \\
13 \\
14 \\
15 \\
16 \\
17 \\
18 \\
19 \\
20 \\
21 \\
22 \\
23 \\
24 \\
25 \\
26 \\
27 \\
28 \\
29 \\
30 \\
31 \\
32 \\
33 \\
34 \\
35 \\
36 \\
37 \\
38 \\
39 \\
40 \\
41 \\
42 \\
43 \\
44 \\
45 \\
46 \\
47 \\
48 \\
49 \\
50\end{array}$ & 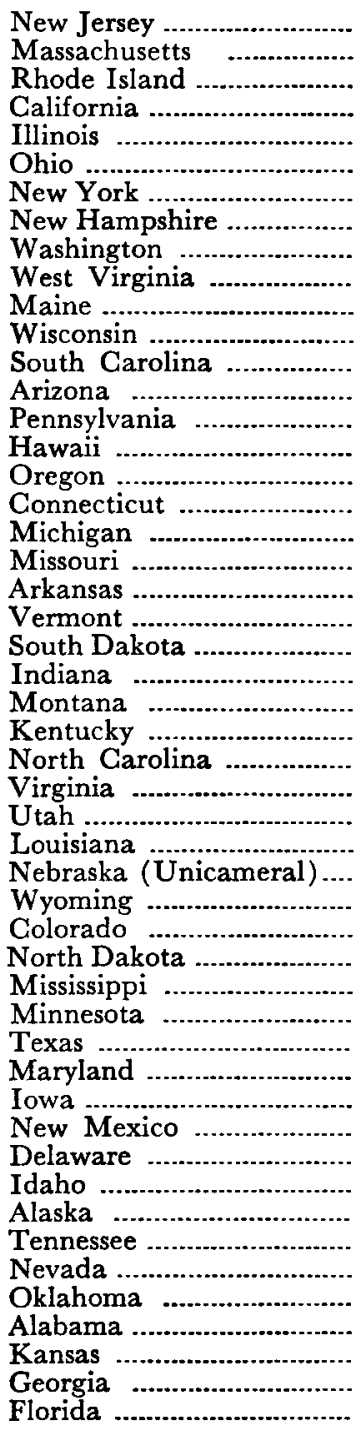 & 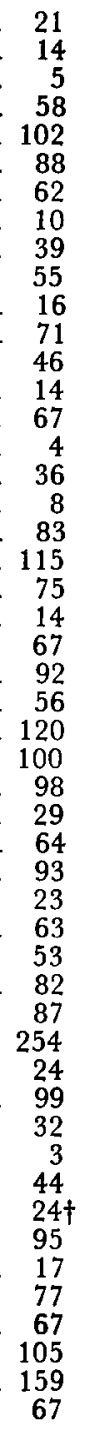 & $\begin{array}{r}5 \\
3 \\
1 \\
3 \\
1 \\
7 \\
5 \\
3 \\
3 \\
11 \\
4 \\
8 \\
9 \\
1 \\
7 \\
1 \\
4 \\
2 \\
4 \\
4 \\
14 \\
4 \\
13 \\
10 \\
8 \\
15 \\
20 \\
17 \\
2 \\
7 \\
9 \\
5 \\
4 \\
10 \\
19 \\
6 \\
11 \\
3 \\
17 \\
5 \\
1 \\
7 \\
2 \\
8 \\
2 \\
9 \\
9 \\
10 \\
15 \\
5\end{array}$ & $\begin{array}{l}53.61 \\
50.76 \\
66.20 \\
50.80 \\
50.88 \\
51.85 \\
52.80 \\
56.84 \\
53.79 \\
53.22 \\
53.08 \\
51.21 \\
50.39 \\
50.95 \\
50.61 \\
79.10 \\
51.99 \\
53.20 \\
52.87 \\
50.98 \\
51.40 \\
52.96 \\
51.52 \\
51.24 \\
51.75 \\
50.00 \\
50.37 \\
50.70 \\
55.44 \\
50.61 \\
50.77 \\
53.40 \\
50.50 \\
50.63 \\
50.87 \\
51.00 \\
51.16 \\
57.69 \\
50.03 \\
51.20 \\
68.90 \\
52.00 \\
55.80 \\
50.87 \\
74.22 \\
50.52 \\
50.90 \\
50.77 \\
50.06 \\
50.40\end{array}$ & $\begin{array}{r}106 \\
105 \\
103 \\
101 \\
100 \\
98 \\
97 \\
96 \\
92 \\
92 \\
92 \\
91 \\
91 \\
91 \\
90 \\
89 \\
89 \\
89 \\
88 \\
87 \\
86 \\
84 \\
83 \\
81 \\
80 \\
80 \\
78 \\
78 \\
76 \\
75 \\
73 \\
73 \\
73 \\
70 \\
70 \\
68 \\
68 \\
67 \\
64 \\
62 \\
62 \\
62 \\
58 \\
57 \\
55 \\
49 \\
48 \\
46 \\
42 \\
29\end{array}$ & $\begin{array}{c}\mathbf{L} \\
\mathbf{L} \\
\mathbf{L} \\
\mathbf{L} \\
\mathbf{L} \\
\mathbf{U} \\
\mathbf{U} \\
\mathbf{U} \\
\mathbf{L} \\
\mathbf{L} \\
\mathbf{L} \\
\mathbf{U} \\
\mathbf{L} \\
\mathbf{L} \\
\mathbf{L} \\
\mathbf{L} \\
\mathbf{L} \\
\mathbf{U} \\
\mathbf{L} \\
\mathbf{U} \\
\mathbf{U} \\
\mathbf{U} \\
\mathbf{L} \\
\mathbf{U} \\
\mathbf{L} \\
\mathbf{U} \\
\mathbf{U} \\
\mathbf{U} \\
\mathbf{L} \\
\mathbf{U} \\
\mathbf{U} \\
\mathbf{L} \\
\mathbf{L} \\
\mathbf{L} \\
\mathbf{U} \\
\mathbf{U} \\
\mathbf{L} \\
\mathbf{L} \\
\mathbf{U} \\
\mathbf{L} \\
\mathbf{L} \\
\mathbf{L} \\
\mathbf{L} \\
\mathbf{U} \text { or } \mathbf{L} \\
\mathbf{L} \\
\mathbf{L} \\
\mathbf{U} \text { or } \\
\mathbf{U} \\
\mathbf{U} \\
\mathbf{L} \\
\mathbf{L}\end{array}$ \\
\hline
\end{tabular}

Rank order correlation between tables I and VI:

$$
\begin{aligned}
& \mathbf{R}=1-\frac{6 \Sigma \mathrm{d}^{2}}{\mathrm{n}^{3}-\mathrm{n}}, \text { where } \Sigma \mathrm{d}=1,896 \\
& \mathbf{R}=1-\frac{11,376}{124,950} \\
& \mathbf{R}=.909
\end{aligned}
$$

* Reproduced from Pierce, Lamb, and White, pp. 272-74.

$\dagger$ Figures are for election districts, since Alaska has no counties. 
TABLE VII

Rank Order of Indices of Representation in House Less Favorable to Counties Having Majority of State Population, 1960 Census*

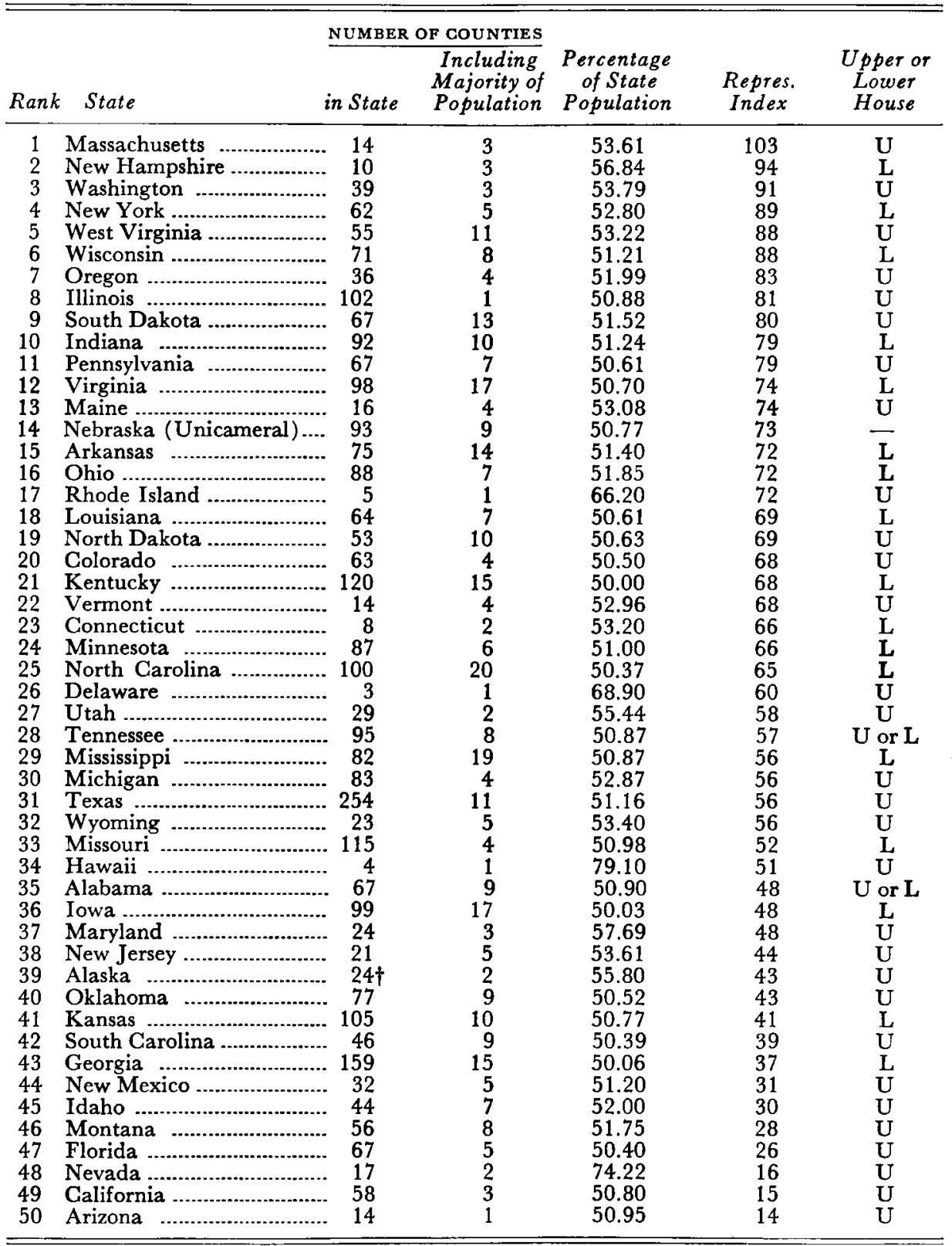

Rank order correlation between Tables II and VII:

$$
\begin{aligned}
& \mathrm{R}=1-\frac{6 \Sigma \mathrm{d}^{2}}{\mathrm{n}^{3}-\mathrm{n}}, \text { where } \Sigma \mathrm{d}=3,762 \\
& \mathbf{R}=1-\frac{22,572}{124,950} \\
& \mathbf{R}=.819
\end{aligned}
$$

* Reproduced from Pierce, Lamb, and White, pp. 272-74.

$\dagger$ Figures are for election districts, since Alaska has no counties. 
states legislature. Feelings of apathy and hopelessness about this situation have given way to a rather manic euphoria since the Baker and Reynolds decisions. Newspapers and magazines have aroused the most far-fetched expectations about "the revolt against hayseed rule." These expectations may be highly unrealistic if it should develop that even the elimination of all or most rural overrepresentation would still leave major political cleavages between a normal statewide majority for governor and other executive offices on the one hand and legislative majorities based on geographic districts on the other.

The embarrassing paucity of political science research on apportionment has already caused courts to resort to some rather pitiful expedients in analyzing the apportionments before them. Political scientists clearly have some important tasks before them. One such task is to determine the extent to which the problem of state legislative representation is (a) an urban-rural problem, and (b) an apportionment problem. To date, the courts have not done so. If, as it seems most probable to us, the real grievances of most of the urban litigants in apportionment cases are far deeper and more complex than the disproportion in population size of legislative districts, we will need analyses of other variables involved in state politics. For example, the extremely uneven distribution of political party strength in most highly urbanized states, when combined with a system of single member districts, may turn out to be a far more important cause of urban frustration than the overrepresentation of rural areas. At any rate, the data and analyses presented in this article suggest the desirability of such new directions for future research. 